The Japanese Journal of Animal Psychology, 45, 2, 51-65 (1996)

\title{
講演論文
}

$$
\text { キンギョのオペラント条件づけ }
$$

立命館大学 藤 健一

\section{Operant Conditioning in Goldfish (Carassius auratus)}

\author{
KENICHI FuJI \\ Department of Psychology, Ritsumeikan University \\ Kita-ku, Kyoto 603-77
}

\section{1. はじめに}

現在この地球上に繁栄する脊椎動物は, 哺乳 類 (約 5000 種), 鳥類 (約 8600 種), そして魚 類（約 40000 種）の 3 種類の脊椎動物といわれ ている (Angermeier, 1986)。脊椎動物の中で, 魚類は最も出現が早く, 現生の魚類の遠い祖先 である無顎類は, 古生代オルドビス紀（およそ 5 億年前から 4 億 4000 万年前の時代）の中期に 出現した。顎をもたない無顎類は極めて原始的 な脊椎動物であるが, 感覚器官としては眼球・ 松果体孔・二半規管をもち, 鯺の種類も少なく 不活発で, 底生ないしは表層性であったらしい。 無顎類は顎を有する有顎類の出現によってデボ ン紀末（およそ 3 億 6000 万年前）に絶滅した。 最初の有顎類の棘魚類は淡水性で, デボン紀に 出現し, 運動器官である鯺も多様化して, 眼球 も大きくなり副次的な嗅覚もあったらしい。石 炭紀末（およそ 2 億 9000 万年前）に絶滅した。 顎の出現は, 脊椎動物の歴史における最大の事 件であり，预そらく捕食効率を上げる要因の一 つになったのであろう。板皮類はいわゆる甲旮 魚と呼ばれる魚類であり，中には泳ぎの速い肉 食魚もいたが, 古生代末には絶滅した。いわゆ るこういった古代魚は，デボン紀の頃にその祖 先が出現した軟骨魚類や硬骨魚類にとって替わ
られた。軟骨魚類は現生のサメの祖先であるが, 硬骨魚よりも原始的であるかどうか疑問とされ ているが, 肺や鰾をもたず捕食性と可動性の高 い魚類である。現生魚の中で最も繁栄している のは, 硬骨魚類であり, 軟質類（デボン紀の頃 出現, 現生のチョウザメの仲間), 全骨類 (三畳 紀の頃出現, 現生のダツの仲間), 真骨類(白亜 紀の頃出現, 現生のほとんどの硬骨魚の仲間) と進化した。硬骨魚類が他の魚類を凌いで発展 した理由は, 5 種類の鯺 (背鯺, 胸鰭, 腹鰭, 臀 鯺, 尾鯺）と鰾（全骨類の頃出現）に浮力の調 節機能が加わったこと（真骨類の頃）によるそ の優れた運動性にあった(コルバート・モラレ ス, 1994)。

キンギョは, フナから人為的淘汰によって作 りだされた園芸品種であるが, 現生の魚類の中 で最も繁栄している真骨類の中の骨鰾目に属す る魚類である。一般に魚類の感覚生理や知覚機 能については水産漁業上の要請からか, 魚類学 者や水産学者による多くの研究も行われ紹介さ れており(川本, 1977; Mostofsky, 1978; Nicol, 1989 ; Douglas \& Hawryshyn, 1990), その中には視力, 色覚, 運動視, 形態視, 大き さと距離知覚, 聴覚, 味覚, 触覚などの研究が 含まれる。たとえば，キンギョの水中の視野に は, およそ $20^{\circ}$ の水平方向で重なる両眼視野が 
あることや(Trevarthen, 1968), 聴覚閾は, 1000 $\mathrm{Hz}$ あたりまでは閾値は低い。一般に水中の振 動は, 魚体が受け止めて鰾の収縮と膨張とに変 換されるが，骨鰾目の魚はこの鰾の収縮と膨張 の振動を, ウェーバー小骨と呼ばれる聴覚補助 器官によって内耳器官に伝達するので, 骨鰾目 は非骨鰾目に比べ聴覚が鋭敏である（古川, 1977)。

魚類の活動は，その活動期によって昼行性と 夜行性とに分けることもできる。アユなどは昼 行性を示し, ナマズなどは夜行性を示す（田畑， 1988)が，キンギョについてははっきりしない。 いずれにしても, 現生の魚類は, 水中という環 境の 5 億年近い淘汰にさらされて, 現在の構造 と機能とが形成され, 今にわれわれの眼前に存 在するのである。

\section{2. キンギョを被験体とした 実験的行動分析法}

オペラント条件づけは, 反応に先立つ先行刺 激（弁別刺激）と，その反応，そして反応に続 く後続刺激（強化子）の 3 要素の関係から分析 できる。先行刺激による反応頻度の統制を刺激 性制御 (stimulus control) とよび, 後続刺激に よる反応頻度の統制を強化スケジュール（reinforcement schedule）という。この 3 要素の関 係を, 三項強化随伴性 (three-term contin- gencies of reinforcement）という。Ferster \& Skinner (1957) はハトを被験体として 5 年 10 カ月にわたる体系的研究を行い, 基本スケ ジュールの基礎的データを蓄積した。

ある動物種で見いだされた行動法則は, 種内 の一般性, 種間の一般性, 課題の一般性などの 次元における一般化について検討される。通常 これらの一般性の検討には, 反復実験を行う。 特に, 種間の一般性の検討には, 異なった動物 種における反復実験が必要となるが，心理学に おける動物学習研究で用いられてきた動物種 は，大部分がラットやハト，サルなどの実験動 物 (laboratory animal) であり，ほとんどが脊 椎動物である (Dewsbury, 1978; 辻, 1978)。強 化スケジュールの研究でも, ヒト以外の哺乳類 と鳥類に集中しており（藤，1987 a)，この傾向 は最近も変わっていない（中島, 1993 ; 佐藤, 1993)。

本稿では, 現生の代表的魚類の真骨類骨鰾目 に属するキンギョ（ワキン, Carassius auratus） において，他の動物種で確認されたオペラント 行動における強化スケジュールの統制の様子を 検討し，その強化スケジュールの種を超えたの 効果の一般性について検討したいくつかの実験 について述べてみたい。

\section{実験装置}

（1） サカナ用スキナー箱 Fig. 1 に概略を示

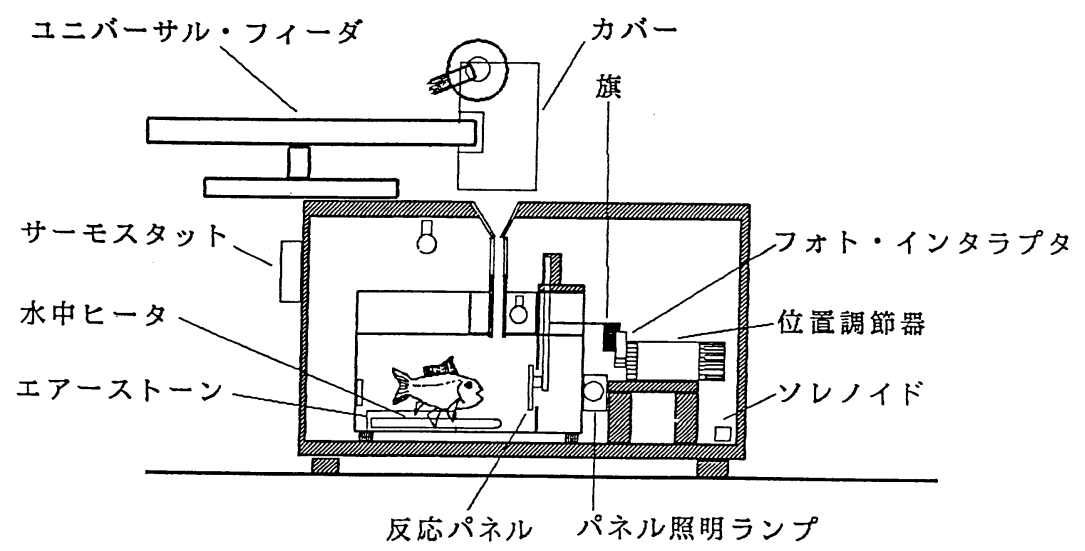

Fig. 1 サカナ用スキナー箱の概略図（藤，1987a） 
した。市販のプラスチック製水槽（16 cm × 26 $\mathrm{cm} \times 18 \mathrm{~cm}$ ）の一端の水中に，反応パネル（半 透明乳白アクリル板で $40 \mathrm{~mm} \times 40 \mathrm{~mm})$ を水面 上からつり下げた。反応パネルは，黒色に塗装 されたアルミ板のほほ中央の開孔部（直径 30 $\mathrm{mm})$ の手前に位置しており, 開孔部の背後にあ たる水槽外の位置に反応パネル照明用の白色ラ ンプが置かれていた。パネル押し反応は，反応 パネルの軸に取り付けられた旗でフォト・イン タラプタのビームを遮らせることにより検出し た。反応パネルの軸には輪ゴムあるいは小さな バネを取り付けて，パネル押しに必要な圧力を ほぼ一定に保つようにした。パネル押しの検出 に必要なストロークは，糊ケースの繰り出し機 構 (コクヨプリットジャンボ) を利用した位置 調整器により, セッションごとに確認し調整で きるようにした。パネル押し反応のフィード バック刺激として，反応ごとに作動するソレノ イドの振動を利用した。この水槽は, ラワン材 の暗箱 (藤, 1982 a) に設置された。強化子の提 示には，暗箱上部に置いた自作あるいは市販の ユニバーサルフィーダ (三双製作所製 UF-100) を用いた。ブラシによって掃き落とされた強化 子は, 暗箱天井部の孔からアクリルパイプを 通って，水槽の水面に提示された。パイプの下 端は水面に合わせてあるので，パイプの区切ら れた水面に強化子が必ず提示された。フィーダ の作動と同時に, 強化子の落下水面をランプで 一定時間照明した。

（2）実験制御装置 種々の強化スケジュール 制御には，自作のシングルボードコンピュータ あるいは市販のパーソナルコンピュータ（エプ ソン HC-20,アドテック ASC73DTS) を用いた (藤, 1980 ; 藤, 1982 b)。

（3）デー夕記録器 オペラント反応を累積記 録器で記録した。市販の記録器 (Ralph Gerbrands C-3) あるいはプリンタで代用(藤, 1984 a)して記録した。この他にデータとして，コン ピュータに反応数, 強化子数などを記録した。

\section{強化子}

強化力, 入手や保存のしやすさ, 取扱いの容 易なこと, 食べさせ過ぎてもキンギョの健康維 持の障害にならないこと, などから乾燥イトミ ミズを用いた。強化子 1 つの大きさが約 $1 \mathrm{~mm}$ 立方になるように，切って使用した。この乾燥 イトミミズは, 水面に落下提示した時にしばら くの間は浮いているので，実験上都合がよかっ た。な抢研究初期には，配合飼料の浮き慨を用 いたこともあった。

\section{飼育水槽}

日常の飼育管理を行う飼育水槽には，市販の プラスチック製の衣料ケース $(19 \mathrm{~cm} \times 58 \mathrm{~cm} \times$ $40 \mathrm{~cm})$ を利用して, 一つの飼育水槽には, キン ギョを多くて 5 匹ないし 6 匹ずつ入れて飼育し た（藤，1983 a)。

\section{3. 各種の正の強化スケジュール}

\section{オペラント反応の形成}

キンギョの水中パネル押し反応の形成法とし て，以下の 4 つの方法を順次試みた。

(1) 漸次接近法によるパネル押し反応の形成 (藤, 1984 b) 実験者のマニュアルによる行動 形成法で，その結果を Fig. 2 に示した。この訓 練場面では，強化子を摂取する反応が十分に完 成していないまま訓練を行ったためもあったた め，パネル押し反応を完成させるのに速い個体 (KI-87)でも 18 セッション, 遅い個体 (KI-84) で 30 セッション近くかかり, 迅速な反応形成訓 練方法としては, 不向きであることがわかった。

（2）強化子の摄取訓練の後にFR 1 を行う訓 練法 (藤，1984b) 飼育水槽に扔いてマニュア ルで提示した強化子を被験体によって摂取する 訓練を十分に行った後, 実験水槽で自発反応が FR 1 (FR スケジュールについては後述)で強化 される訓練場面にさらす方法を試みた。その一 例を Fig. 3 に示した。300セッションの強化子 摂取訓練後, FR 1 に入れた最初のセッションか ら,パネル押し反応は自発し, 3 セッションめに はほぼ安定した反応が得られた。

（3） FT 訓練の後に FR 1 を行う訓練法(藤， 


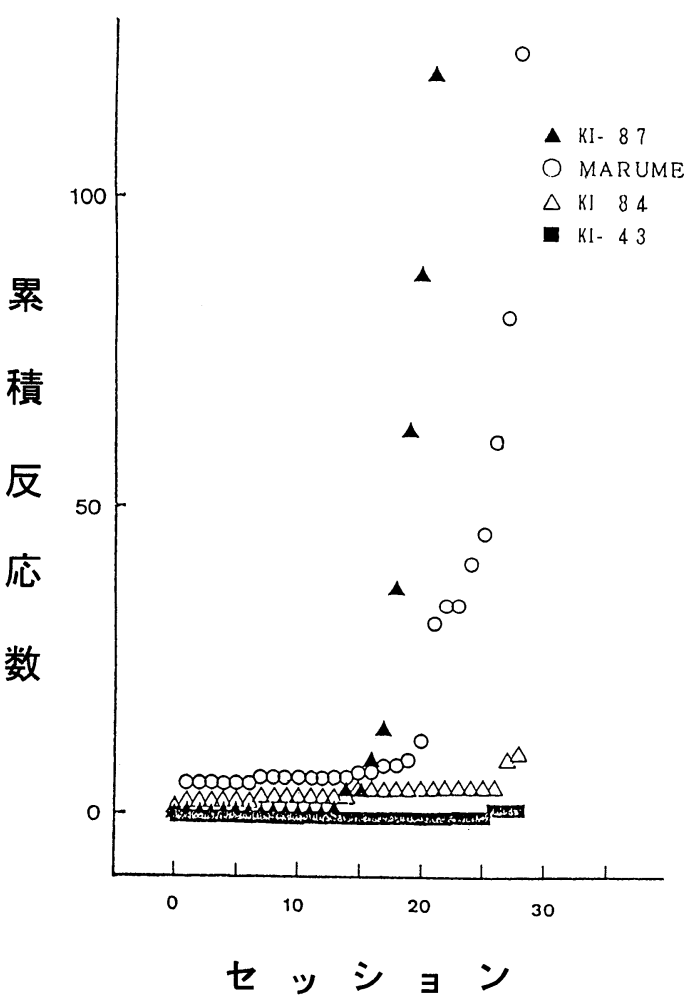

Fig. 2 漸次接近法によるキンギョのパネル 押し反応の形成（藤，1984b)
1984 b) 強化子の摂取場面を, 実験者のマニュ アルによる方法から，FT スケジュール (fixed time reinforcement schedule; 定時強化スケ ジュール）に変更した方法である。FTスケ ジュールでは, 前回の強化から $\mathrm{t}$ 秒経過した時 に，反応の有無にかかわらず強化子を提示する。 実験水槽と同大の専用訓練水槽（水中反応パネ ルは取り払ってある)で，FT 30”訓練を所定の セッション数 (4 から 40) 実施した後に, FR 1 へ移行した。Fig. 4 に一例を示した。FT 訓練が 4 セッションでも FR 移行直後から, パネル押 しの自発反応が出現し, 以後反応は安定した。

(4) FRと時間スケジュールの論理和スケ ジュールによる訓練法（藤，1992）論理和ス ケジュールでは，同時に作動する複数のスケ ジュール（たとえば FR と FT) のうち，いずれ かのスケジュールの強化の条件が満たされたな らば，そこで強化子が提示される。強化子の捸 取訓練は飼育水槽で 1 セッションだけ行い, 以 後は実験水槽で alt FR FT (alternative FR FT) ないしは, alt FR VT (alternative FR VT) に移行する訓練法を行った。VTスケジュール

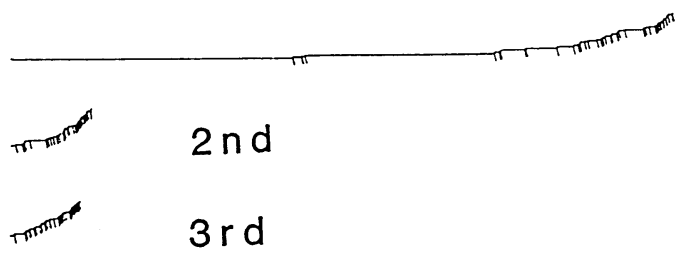

$1 \mathrm{st}$

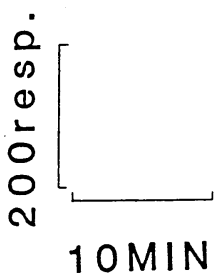

$\mathrm{K} 1802$

强化子摂取訓䓶

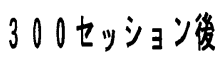

Fig. 3 強化子摂取訓練後のFR1による訓練法（藤，1984b）

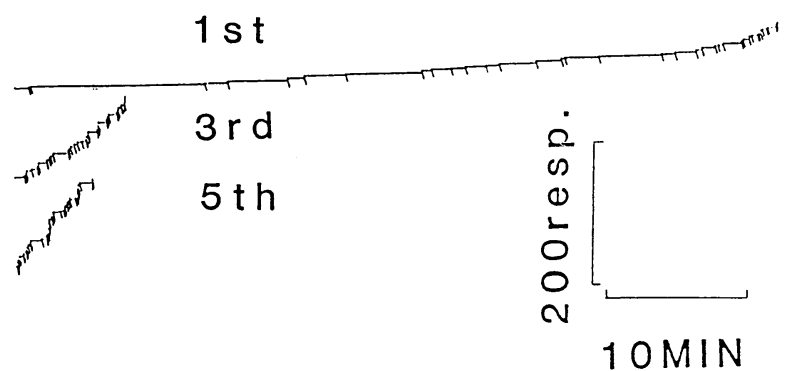

$\mathrm{K} / 211$

通化子摄取部莱

4 セッション後

Fig. 4 FT訓練後のFR1による訓練法（藤，1984b） 
(variable time reinforcement schedule; 変 時強化スケジュール）とは, 前回の強化から平 均すると $\mathrm{t}$ 秒経過した時に, 反応の有無にかか わらず強化子を提示する方法である。Fig. 5 に その例を示した。KI-102 は alt FR 1 FT 15”の 訓練を 1 セッション実施した後に, FR 1 に移行 させたところパネル押し反応が形成できた。 KI -105 は通算 6 セッションめの訓練条件が alt FR 1 VT 120”で， 7 セッションめに FR 1 に移 行したところ, 反応が形成された。

反応形成訓練では, 強化子の確実な摂取行動 が反応形成訓練に先立って完成していることが 肝要であり，上記の(4)の訓練方法によれば，被 験体としてのキンギョ（すなわちパネル押し反 応を自発できるキンギョ）の迅速な供給が可能 であることがわかった。魚類を対象とした自動 反応形成については，キンギョ（Woodard＆

KI-102

alt FR1 FT15"

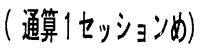

FR1

(通算2セッションめ)

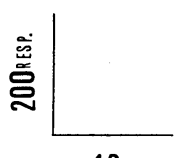

KI-105

10 mIn

alt FR1 VT20"

(通算6セッション(女)

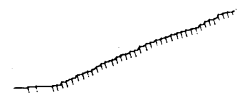

FR1

(通算7セッションめ)

Fig. 5 論理和スケジュールによる訓練法 (藤，1992)
Bitterman, 1974 ; Bottjer, Scober \& Wallace, 1977 ; Brandon \& Bitterman, 1979), ティラ ピイア，ボラ，カマス (Squier, 1969), テッポウ ウオ（Waxman \& McCleave, 1978）などが報 告されている。

FR スケジュール (fixed ratio reinforcement schedule；定率強化スケジュール)

FR スケジュールは, 前回の強化から一定の 反応が自発すると次の強化子が提示されるスケ ジュールである。種々の FR 值の下での安定し た反応のいくつかの例を, Fig. 6 に示した。FR スケジュールに典型的な break and run が生じ た。FR の消去の例を Fig. 7 に示した。消去に 移行した後は, 反応が頻発と休止とを繰り返し ながら減少した。

VR スケジュール (variable ratio reinforcement schedule ; 変率強化スケジュール)

VR スケジュールは, 前回の強化からある回 数の反応が自発すると次の強化子が提示される が，その強化に必要な反応回数は強化ごとに異 なっているスケジュールである。Fig. 8 に種々 のVR 值の下での安定した反応のいくつかの 例を示した。FR と異なり，強化後休止 (PRP； post reinforcement pause）がほとんど無いか, 非常に短くなった。全体反応率は, 同じ FR 值と 比べても高かった。Fig. 9 にVRの消去におけ る反応の変容を示した。消去に移行した後も FR 消去で出現した反応休止はほとんど出現せ ずに，全体反応率が徐々に低下していった。

FI スケジュール (fixed interval reinforcement schedule；定時隔強化スケジュール)

FI スケジュールは, 前回の強化からの一定の 時間が経過すると, 環境側が強化の準備状態と なり, その後の最初の反応によって次の強化子 が提示される。種々の FI 值の下での安定した 反応の例を, Fig. 10 に示した。FI 4' までの值の 下では，ハトで観察されるような顕著な反応加 速は生じなかったが，FI 值を 15 以上にとると 反応加速が起こった。全体反応率は, FR や VR に比バて低かった。また，安定したと思われる 
動物心理学研究 第 45 巻第 2 号

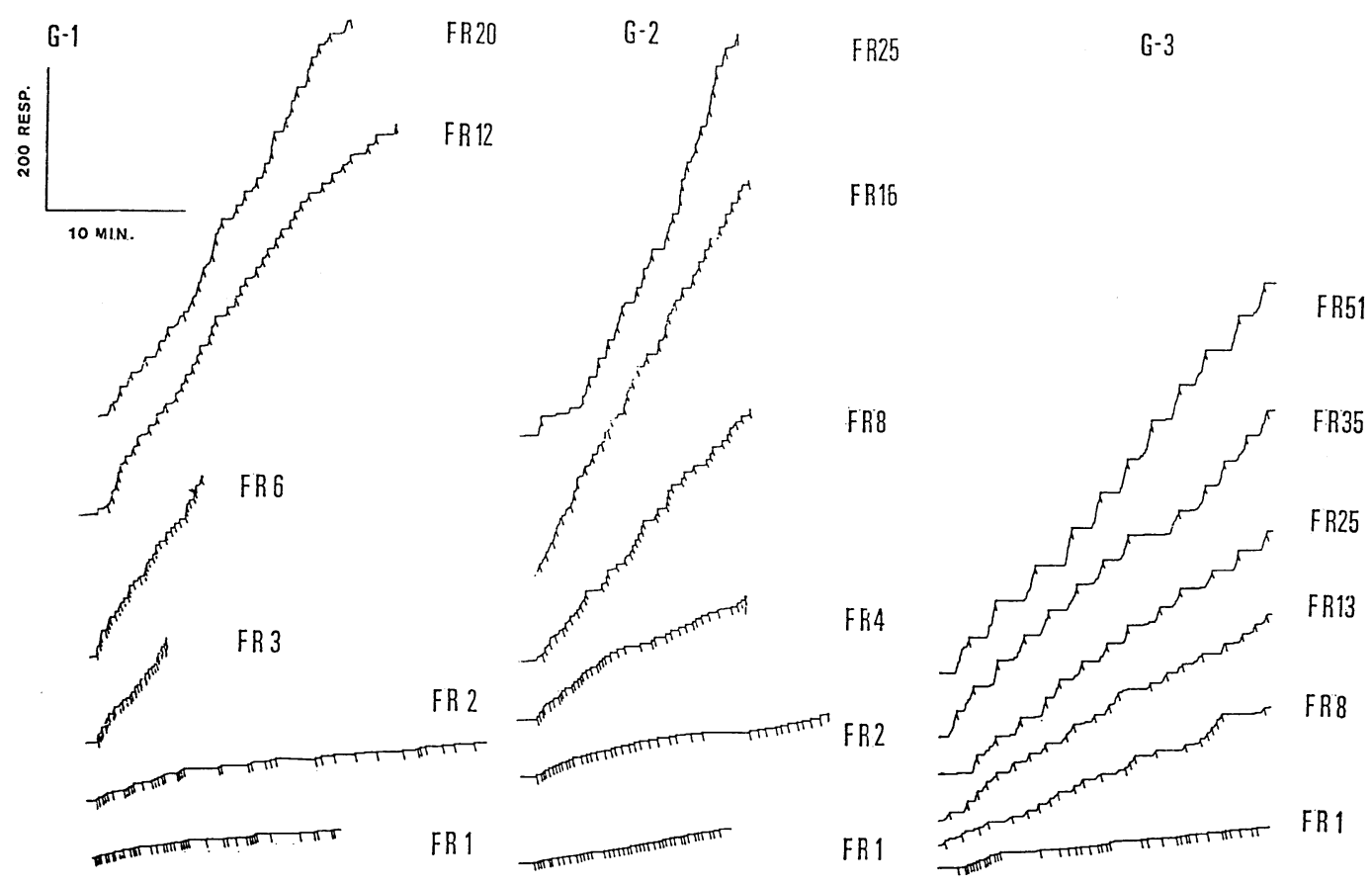

Fig. 6 FRスケジュールの累積記録（藤，1987a）

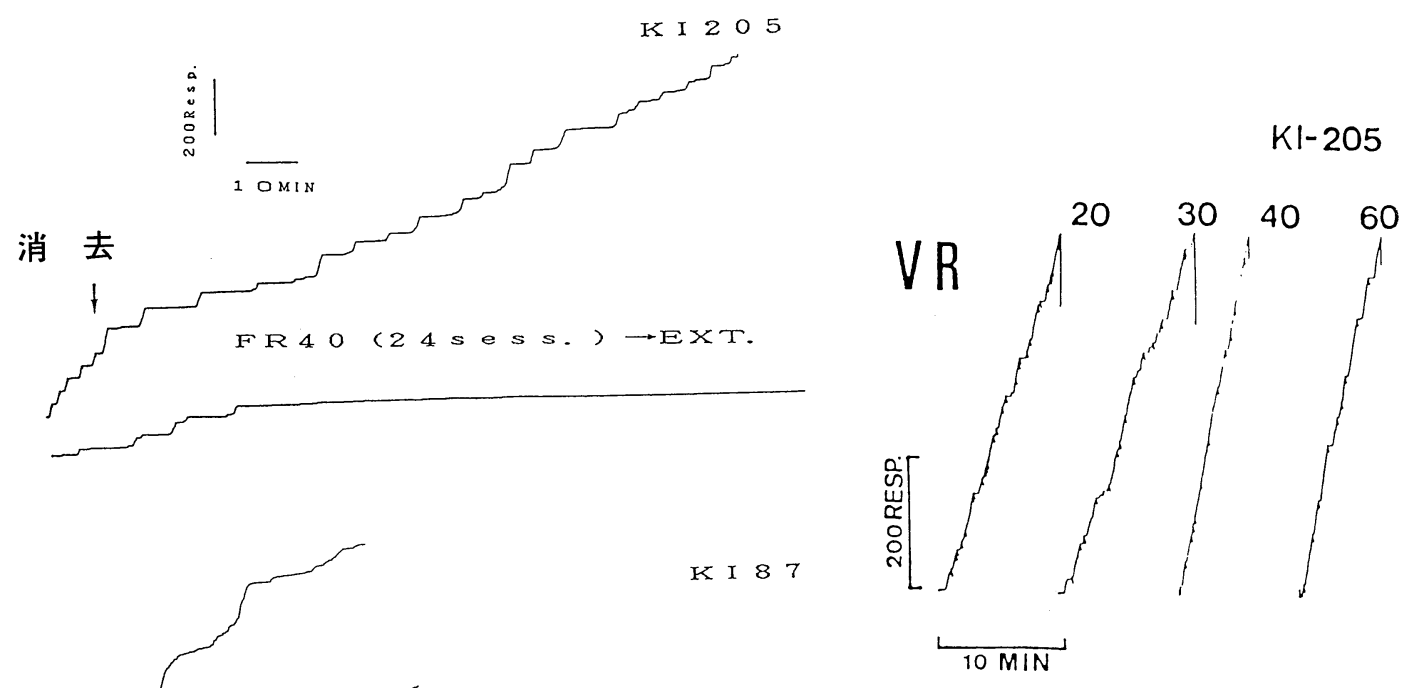

Fig. 8 VRスケジュールの累積記録

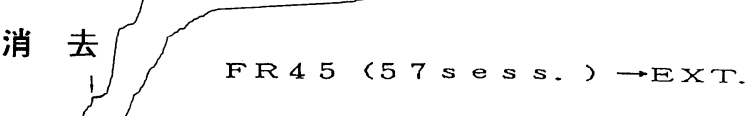
(藤，1983b）

Fig. 7 FRスケジュールからの消去（藤，1987a） 

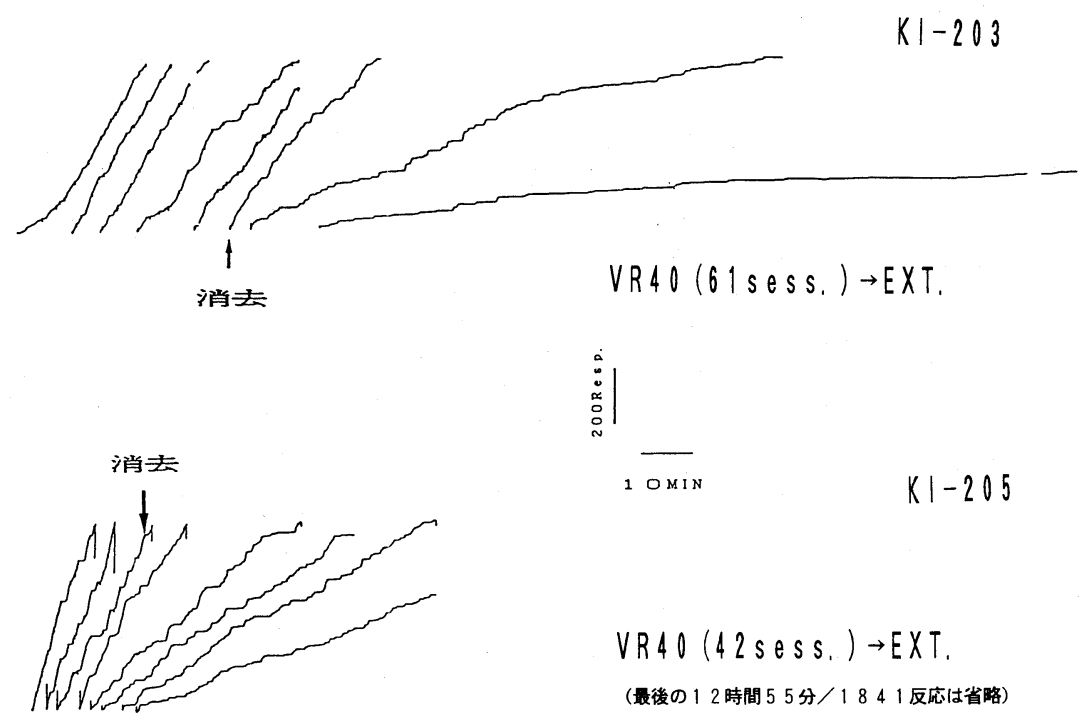

Fig. 9 VRスケジュールからの消去（藤，1987a）

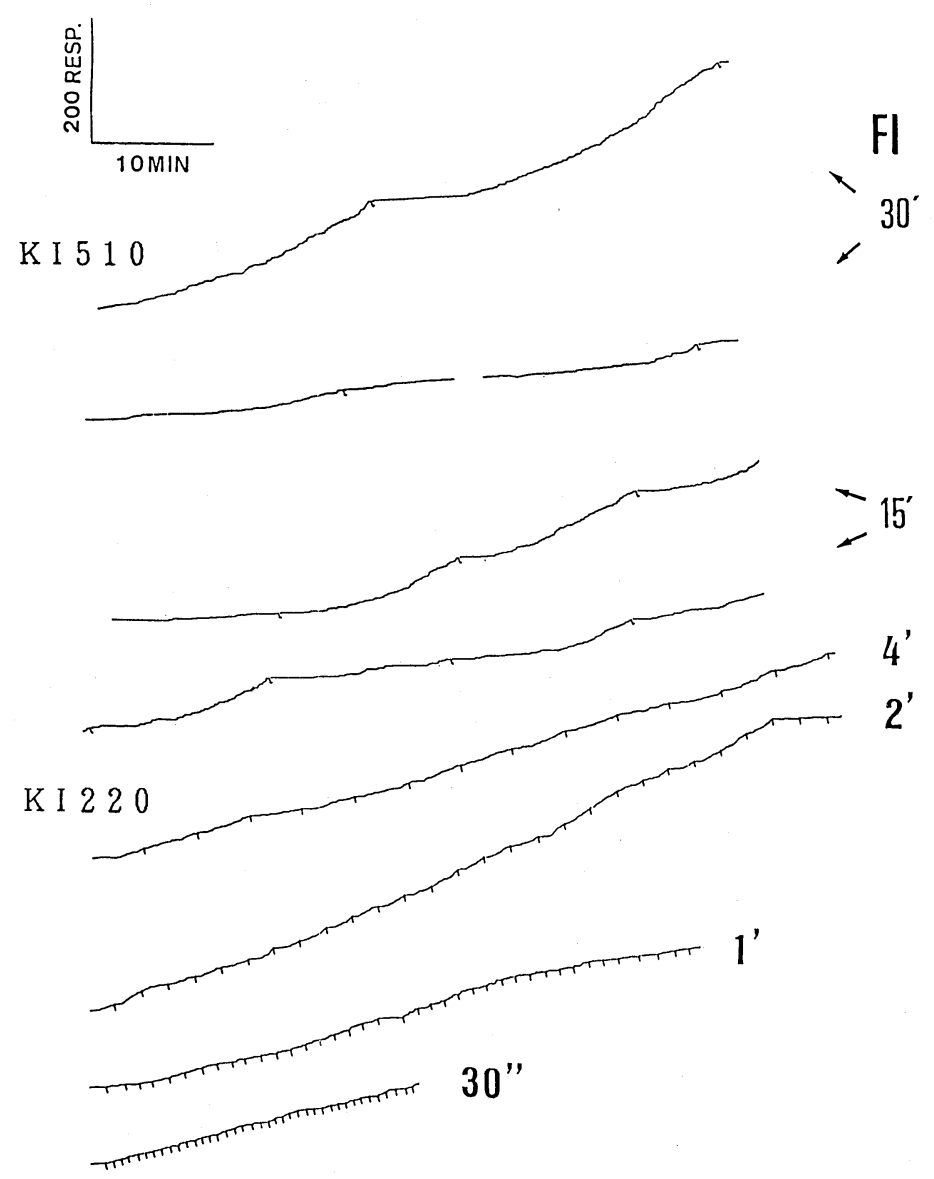

Fig. 10 FIスケジュールの累積記録（藤，1987a） 
FI 反応の形成は FR に比べても長期間を要し, KI-220 の FI 4’の場合でも 49 セッション計 132 時間 59 分であった。Fig. 11 に FI の消去に おける反応の変化を示した。KI-510 はFI 5’か らの消去であり，KI-220 は FI 1'からの消去へ の移行であった。いずれの被験体も, 強化中の 反応パタンを維持しながら, 局所反応率の上下 を繰り返しながら，全体反応率を低下させて いった。

VI スケジュール (variable interval reinforcement schedule；変時隔強化スケジュール)

VIスケジュールは, 前回の強化から次の強化 の準備状態になるまでの時間間隔が, 強化のご とに変動するスケジュールである。Fig. 12 に 種々のVI 值の下での反応を示した。VR スケ ジュールと同様, 強化後反応休止はほとんど出 現しないが，VR スケジュールよりも全体反応
率が低く，同值の FI とほほ同じかやや高めの 反応率となった。Fig. 13 に VI から消去に移行 した時の反応の変容を示した。反応休止なしに， 非常に滑らかな反応率の低下を示した。

DRL スケジュール (differential reinforcement schedule of low rate ; 低反応率分化強化 スケジュール)

前述のように, FI 下の反応加速は FI 值がか なり大きくなって初めて顕著になった。これは, キンギョの時間弁別行動のある側面を示してい る可能性もある。そこで, 時間弁別行動を DRL スケジュールを用いて, 直接検討した(藤, 1987 b ; 藤, $1988 \mathrm{a}$; 藤, 1988 b)。DRL スケジュー ルは, 所定の経過時間以前の反応は強化をキャ ンセルし，その経過時間後の反応のみを強化す る。実際には,いわゆる連鎖スケジュール (chain schedule) のコンポーネントにDRLを組み込

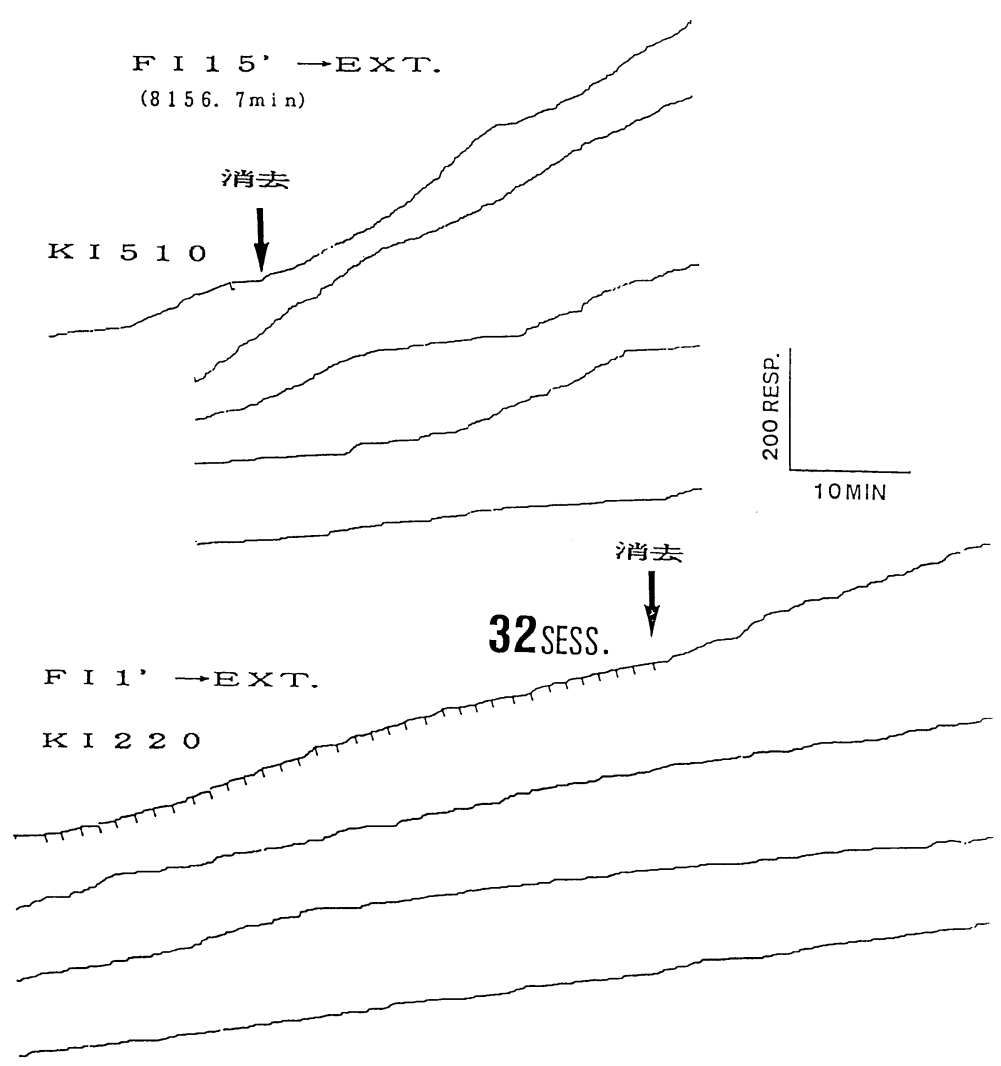

Fig. 11 FIスケジュールからの消去（藤, 1987a） 
藤：キンギョのオペラント条件づけ

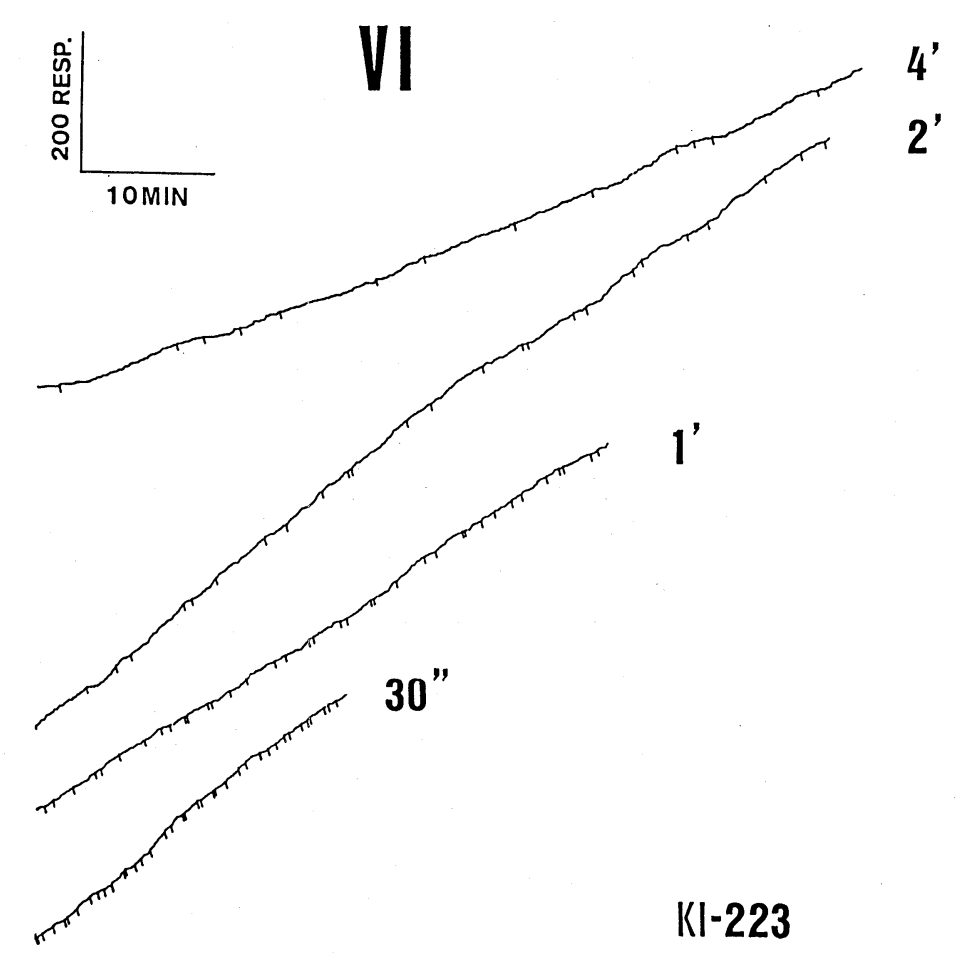

Fig. 12 VIスケジュールの累積記録（藤，1984c）

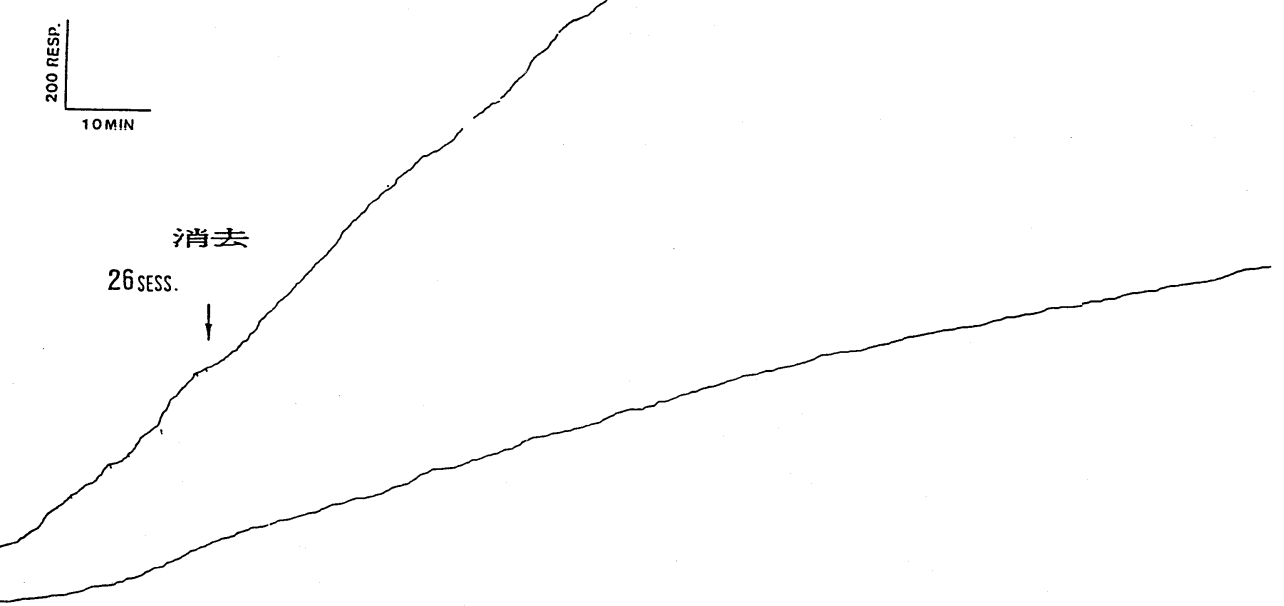

Fig. 13 VIスケジュールからの消去（藤，1984c） 
Chain FRI DRL10" L. H 11"

KI-500

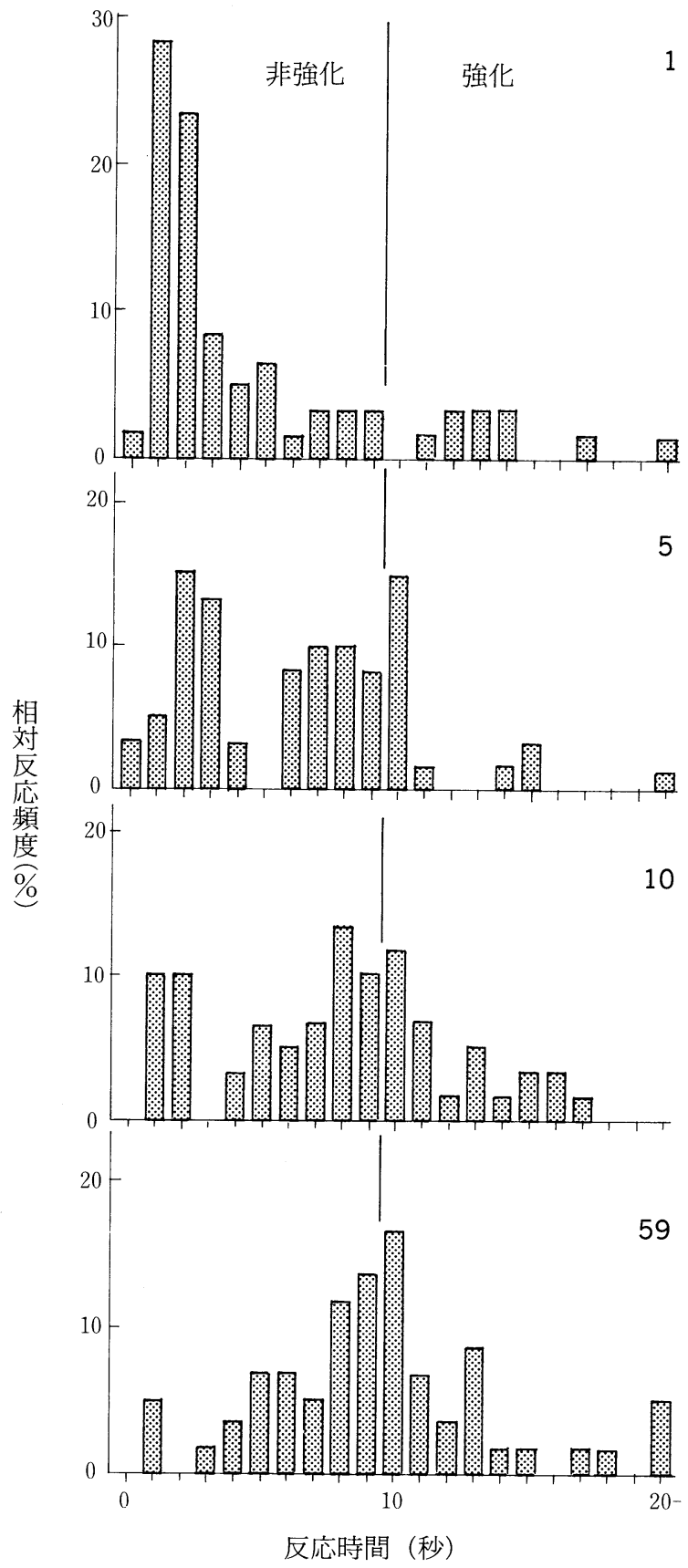

Fig. 14 DRLスケジュールにおける反応時間 分布の変容。訓練 1 セッションめから 59セッションめまでを示した”(藤, 1988b) んで使用した（chain FR 1 DRL 10”，リミテッ ド・ホールドを 11 秒とした)。各試行において, 最初の反応 (パネルは緑色に照明)により DRL に移行する (パネルは赤色に変化)ようにした。 DRL 值 10”に達する間の反応は, その試行の強 化をキャンセルした。種々の条件下で訓練を 行ったが, DRL 行動を形成し易くするために, そのフライング反応が DRL 值 10”に近ければ 近いほどブラックアウトが短くなる方法を用い た(藤，1988 b)。ブラックアウトは最長で 20 ”, 最短で 2 ”であった。強化可能状態に移行後 11 ” 以上無反応の場合は, 強制的にその試行は終了 してITI の後, 次の試行に移行した。結果の一 例を Fig. 14 に示した。訓練の初期には DRL 移

5 行直後の反応が頻発していたが, 10 セッション めあたりから反応時間のピークは DRL 值に近 づき，59 セッションめには DRL 值まで遅延す るようになった。キンギョでもこのような訓練 を施せば，比較的「短い」時間の経過時間を弁 別刺激とする弁別行動を形成できることがわ かった。

\section{4. キンギョの摂食行動の分析}

飼育水槽での付加的給慨量と実験水槽での反 応の変容

スキナー箱の中の動物の行動は，その被験体 が現に直面している環境要因の統制を受けるこ との外に，その被験体の実験場面以外における 環境要因の統制をも受けている。ハトを用いる 研究で，体重統制手続きによって反応に後続す る環境事象（強化子）の強化力を統制できるの も, この理由による。魚類や爬虫類などは, 哺 乳類や鳥類と異なり成長に限界がないため, キ ンギョでは体重統制手続きを利用しにくい。そ こで, 実験水槽場面での条件は一定にしたまま, 飼育水槽での給餌量を変化させ，実験場面での 強化スケジュールの行動統制力の変化を調べた (藤， 1983 c)。実験水槽での条件は，FR 45 で 1 セッション最大 40 強化を上限とした。強化子 は乾燥イトミミズ（1個が約 $1 \mathrm{~mm}$ 立方で， 40 
強化で計約 $100 \mathrm{mg}$ )を用いた。この実験水槽で 被験体が摂取する強化子の他に, 実験終了後の 夕刻のほぼ一定の時刻に飼育水槽で付加的な餌 を与えた。フレーク状の餌 $400 \mathrm{mg}$ の条件(「貧 しい」条件）と, フレーク状の餌 $400 \mathrm{mg}$ にさら に乾燥イトミミズ $500 \mathrm{mg}$ を加えた条件(「豊 か」条件）との 2 条件を設定した。実験は，飼 育水槽が「貧しい」条件の場合の FR 45 での反 応が十分安定してから, 飼育水槽での餌条件を

「豊か」条件に変更した。2 匹の内の一例の結果 を Fig. 15 に示した。飼育水槽での餌供給を豊 富にしても, 実験水槽での FR パフォーマンス を急激に変化させないこと, また, 局所反応率 にはさほどの低下は起こさずに, 強化後反応休
止を延伸しながら全体反応率を低下させていつ たことが読み取れる。

\section{4 時間連続実験場面}

古くは Hellwald (1931) が, マウスについて 自然的食事律を分析しているが，一般にその個 体の摂食可能な場面を実験箱に限定し, 摄食行 動を被験体のオペラント反応に依存させる 24 時間連続実験場面を用いれば，摂食行動を統制 している生物学的要因を検討することができ る。

（1） 24 時間連続実験場面における単一強化 スケジュールの統制力の違い（藤，1985）実 験水槽の照明は明期・暗期が 12 時間ずつで, 餌 は反応によって摂取する強化子の乾燥イトミミ

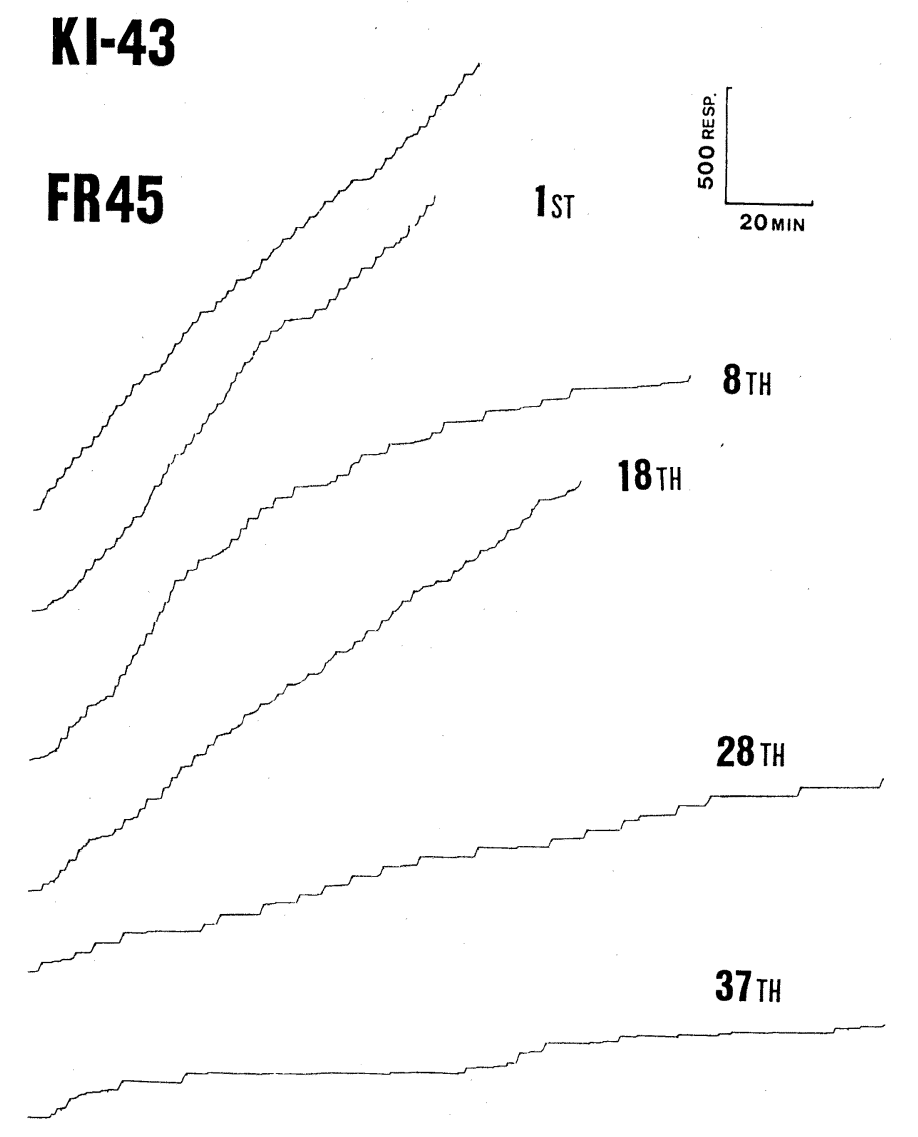

Fig. 15 飼育水槽の付加的給餌量を増加した後の, 実験水槽におけ

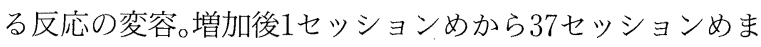
でを示した（藤，1983c） 
ズのみの封鎖餌環境とした。強化スケジュール は，事前の検討により時間当たりの強化量がほ ぼ等しいと考えられたFR 500 とVI 32’とを用
いた。 4 日間連続して行った累積記録の一部を， Fig. 16, Fig. 17 に示した。VI スケジュールで は1日の時間帯にかかわらず，ほぼ同じ反応率
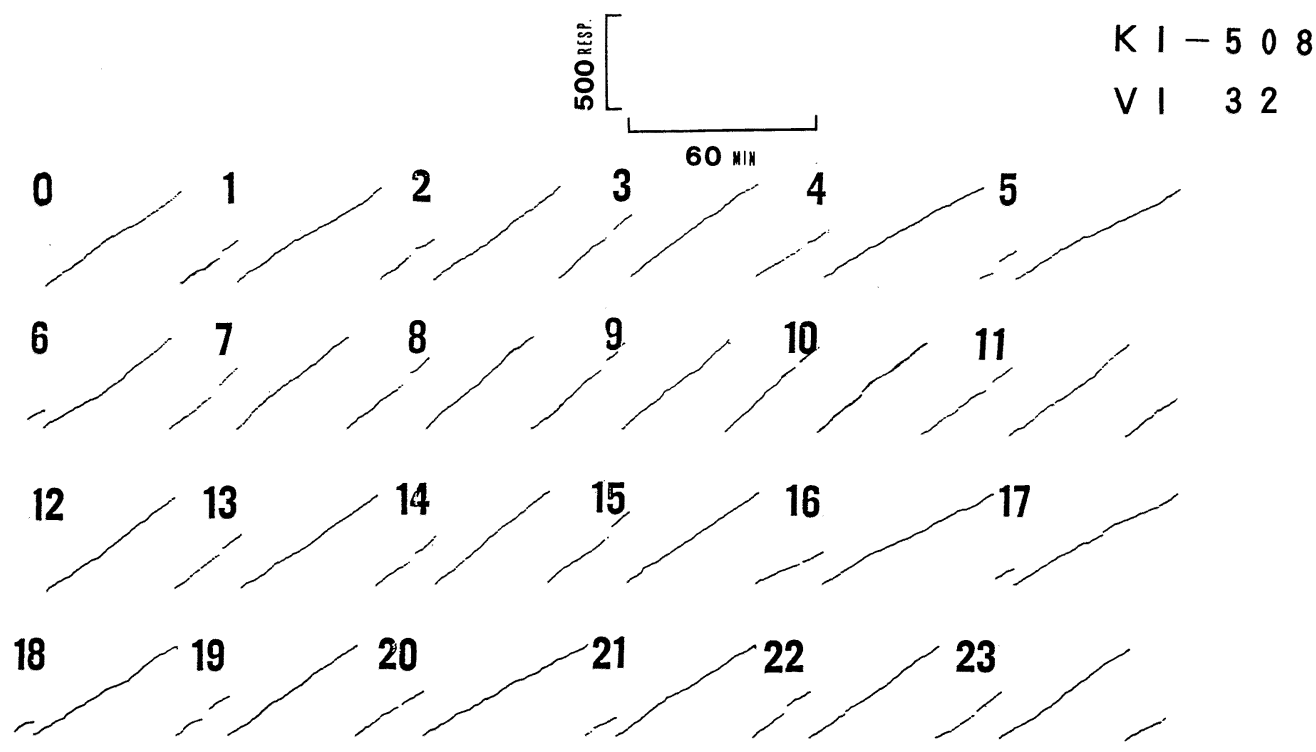

Fig. 16 VI32’ で強化される24時間連続実験場面での累積記録。図 中の数字は時刻を表す（藤，1985）
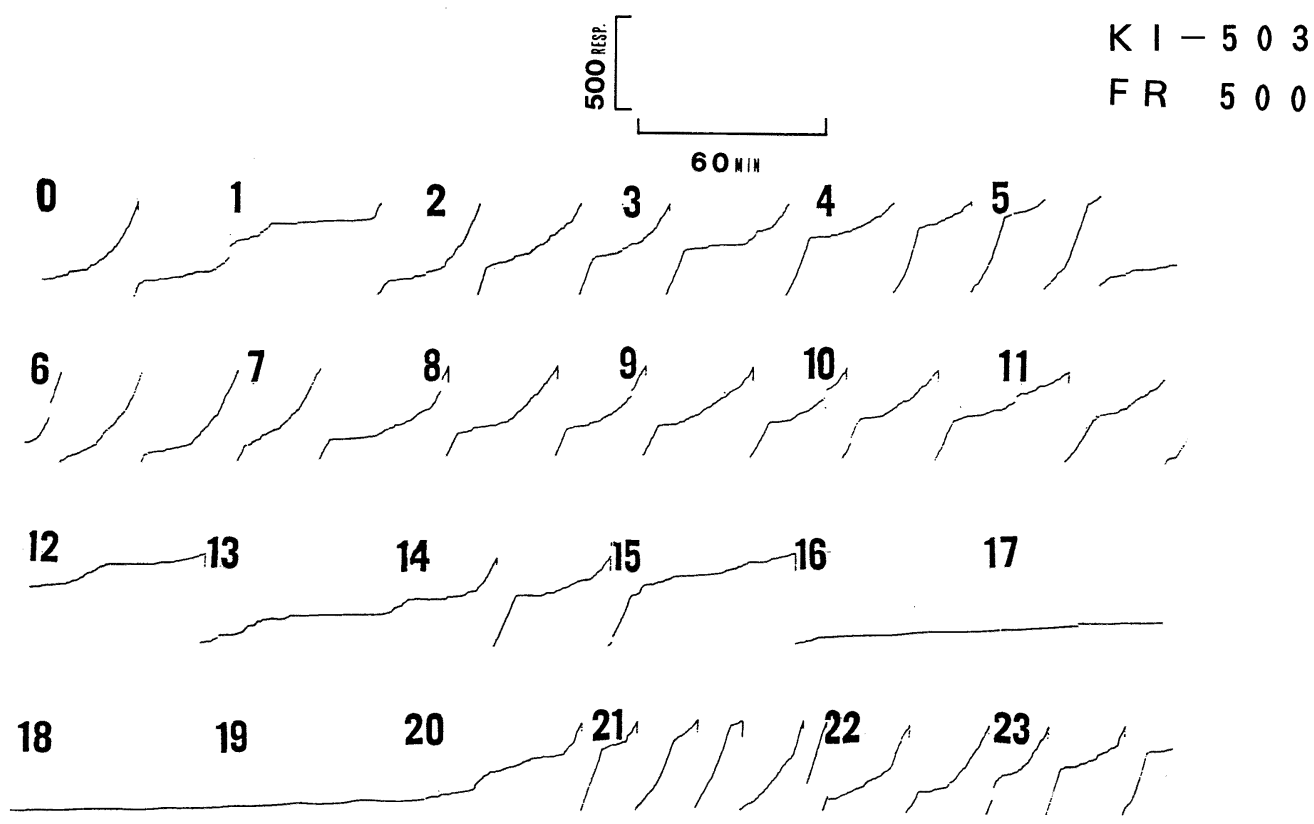

Fig. 17 FR500で強化される24時間連続実験場面での累積記録。図 中の数字は時刻を表す（藤，1985） 
（350 反応／時間から 500 反応／時間）を示し たが, FR スケジュールでは高い反応率(1000 反 応 /時間から 1200 反応／時間)の時間帯と, 低 い反応率 $(600$ 反応/時間から 900 反応/時間) の時間帯とに分かれた。この FR と VI の反応 傾向は，4 日間を通して観察された。24時間連 続実験場面を設定することにより，キンギョに おける時隔スケジュールと比率スケジュールと の違いが，このような形で出現したのかもしれ ない。また FR の反応パタンに, FI パフォーマ ンスと同様の反応加速が生ずることが付随的に 見いだされた。

（2）摂食可能機会配分の効果（藤，1986） 1 日の中で摂食の可能な時間帯と不可能な時間帯
とを作り，それを環境側のスケジュールによっ て統制した場合，キンギョは摂食行動をどの様 に時間配分するのだろうか。1日あたりの摂食 可能の時間の合計を 6 時間に一定にして, 4 時 間おきに 1 時間の捸食可能時間 $\times 6$ 回, 2 時間お きに 30 分の摂食可能時間 $\times 12$ 回, 1 時間おきに 15 分の攝食可能時間 $\times 24$ 回の 3 種類の摂食可 能機会の配分条件（すなわち摄食機会について の環境側のスケジュール）を設けた。実験は上 述の実験と同様の 24 時間連続実験場面を用い た。摄食可能時間での強化スケジュールは FR 64 を, 摂食不可能時間は EXTを用いた。結 果をFig. 18 に示した。摂食可能時間の合計は 同じであるにもかかわらず，摂食可能機会が多

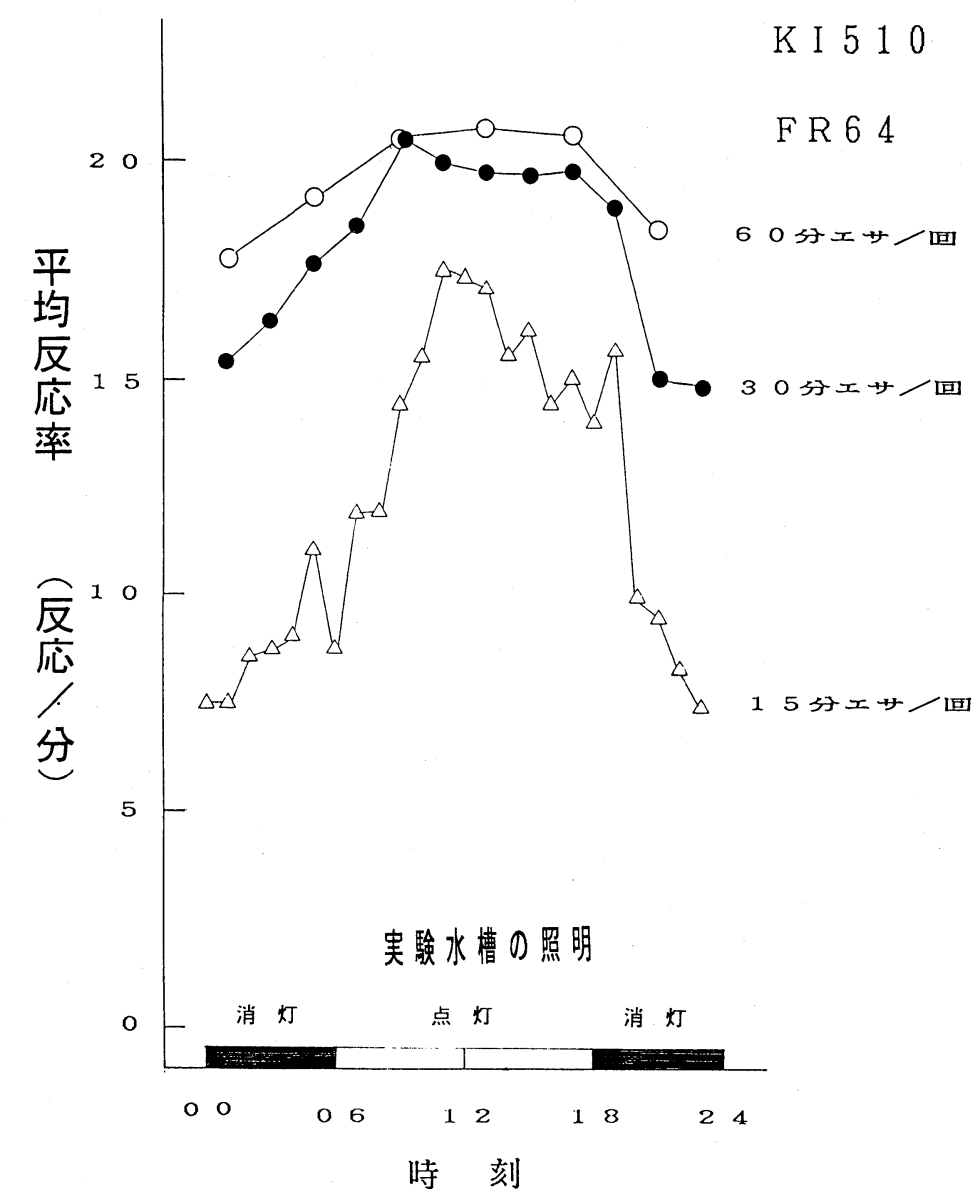

Fig. 1824 時間連続実験場面における摂食可能機会配分の違いが反 応率に及ぼす効果（藤，1986） 
いと，キンギョは「夜間」時間帯に比べて「昼 間」時間帯の反応率を増加させた。捸食の機会 を減らすと，「真夜中」でも「昼間」と同じ程度 の摂食行動を示し，1日あたりの強化子総数は， 摂食機会の多い場合よりも増加することがわ かった。もし，その動物の活動性を反応に基づ く摂食行動を指標として定義するならば，少な くともキンギョの活動性は，1つの餌を摂取す る強化スケジュールと, その摄取の機会を提供 する環境のスケジュールとによって統制されて いる。家庭などで普段見慣れている「金魚」が 夜はおとなしいのは, キンギョの「昼行性」が 原因なのではなくて，その飼育環境が提供する スケジュールによって, そのように行動が統制 されているからである。

\section{5.まとめ}

行動実験の実験動物として多用される脊椎動 物のハトやラット，サルなどにおいて見いださ れた強化スケジュールの機能について, 系統発 生的に遠い共通の祖先を持つ現生の魚類の真骨 類骨鰾目のキンギョを対象に選び, 反復実験を 行った。その結果, 正の強化スケジュールの行 動統制機能は,キンギョにおいても確認された。 しかしながら，魚類を対象とした強化スケ ジュール研究には多くの強化スケジュールが未 着手のまま残されており，こういったスケ ジュールが，既にその行動統制力が確認された 動物種におけるのと同様の統制力を有している という保証は無い。また, 魚類は陸生動物と異 なり, 環境に直接はたらきかける身体器官が限 定されており，このことがオペラント行動にも たらす制約についても研究される必要がある。 さらに，脊椎動物とは異なった進化の道筋をた ぞって現在に至った他の動物種，たとえば節足 動物や軟体動物における強化スケジュールの行 動統制力の体系的分析は，現在のところ非常に 少ない(Abramson, 1986)。

行動分析学の進むべき一つの方向としての行 動分析学的比較行動学ないしは行動進化学（佐
藤，1993）は，体系的実験の行われることの少 なかった脊椎動物や無脊椎動物についての強化 スケジュール研究をも要請していると考えられ る。

\section{REFERENCES}

Abramson, C. I. 1986 Invertebrates in the Classroom. Teaching of Psychology, 13, 24-29.

Angermeier, W. F. 1986 The evolution of operant learning and memory. A Comparative EthoPsychology. Basel : Karger.

Bottjer, S. W., Scober, S. R. \& Wallace, J. 1977 Positive behavioral contrast, autoshaping, and omission responding in the goldfish. Animal Learning \& Behavior, 5, 336-342.

Brandon, S. E. \& Bitterman, M. E. 1979 Analysis of autoshaping in goldfish. Animal Learning \& Behavior, 7, 57-62.

コルバート E. H.・モラレス M. 田隅本生（監訳） 1994 脊椎動物の進化 原著第四版 築地書館 (Colbert, E. H. \& Morales, M. 1991 Evolution of the Vertebrates. 4th ed. New York: John Wiley \& Sons.)

デュースバリィ D. A. 奥井一満（訳） 1981 比 較・動物行動学 共立出版

(Dewsbury, D. A. 1978 Comparative Animal Behavior. New York: McGraw-Hill.)

Douglas, R. H. \& Hawryshyn, C. W. 1990 Behavioral studies of fish vision : an analysis of visual capabilities. In R. H. Douglas \& M. B. A. Djamgoz (Eds.), The Visual System of Fish. London: Chapman and Hall. Pp. 373418.

Ferster, C. B. \& Skinner, B. F. 1957 Schedules of reinforcement. New Jersey: Prentice-Hall.

藤 健一 1980 ワンボード・マイクロコン ピュータの動物実験における利用 日本心理 学会第 44 回大会発表論文集, 31 .

藤 健一 1982 a サカナ用スキナー箱の製作 心理学ラボラトリ・コンピュータ研究会テク 
ニカル・レポート 1, 62-66.

藤 健一 $1982 b$ 心理学の実験制御とマイクロ コンピュー夕 立命館文学, $439: 441,1-31$.

藤 健一 $1983 \mathrm{a}$ 心理学の実験動物としてのキ ンギョの飼育 立命館文学, 457:459, 1-18.

藤 健一 1983 b キンギョに打ける比率スケ ジュールの検討 関西心理学会第 95 回大会 発表論文集, 5 .

藤 健一 1983 c キンギョの摂食行動の分析 日本心理学会第 47 回大会発表論文集, 377.

藤 健一 1984 a EPSONターミナルプリンタ RP-80 で累積反応記録を書く PLANET, 3, 29.

藤 健一 1984 b キンギョのパネル押し行動の 形成 動物心理学年報, 34, 38 ( 抄録).

藤 健一 $1984 \mathrm{c}$ キンギョにおける間隔スケ ジュールの検討 関西心理学会第 96 回大会 発表論文集, 20.

藤 健一 1985 キンギョの 24 時間連続実験に よる摄食行動の分析 日本心理学会第 49 回 大会発表論文集, 108 .

藤 健一 1986 キンギョの摂食行動における摂 食可能時間配分の効果 動物心理学年報, 36, 130 (抄録).

藤 健一 1987 a キンギョにおける単一強化久 ケジュールの検討 立命館文学, 500, 61-92.

藤 健一 1987 b キンギョにおける低反応率 分化強化訓練 関西心理学会第 99 回大会発 表論文集, 16 .

藤 健一 1988 a キンギョにおけるDRL スケ ジュールの検討 動物心理学年報, 38, 48 （抄 録).

藤 健一 1988 b キンギョにおける低反応率 分化強化訓練 (その 2) 関西心理学会第 100 回大会発表論文集, 46.

藤 健一 1992 複数個体場面におけるキンギョ のオペラント行動の分析(2) 日本心理学会第 56 回大会発表論文集, 452.
古河太郎 1977 聴覚 川本信之（編） 1977 魚 類生理改訂増補 第 22 章恒星社厚生閣 Pp. 491-512.

Hellwald, H. 1931 Untersuchungen über Triebstärken bei Tieren. Zeitschrift für Psychologie, 123, 94-141.

川本信之(編) 1977 魚類生理 改訂増補 恒星社 厚生閣

Mostofsky, D. I. (Ed.), 1978 The Behavior of Fish and Other Aquatic Animals. New York: Academic Press.

中島定彦 1993 さまざまな動物種を用いたオぺ ラント条件づけの諸研究 (未公刊, FD 配付資 料)

Nicol, J. A. C. 1989 The Eyes of Fishes. Oxford: Clarendon Press.

佐藤方哉 1993 行動分析学における動物実験の 役割 ——理論 $>$ の敗退と反復実験の勝利 — 心理学評論, 36, 209-225.

Squier, L. H. 1969 Autoshaping key responses with fish. Psychonomic Science, 17, 177-178.

田畑満生 1988 鱼類の日周行動と概日リズム 羽生 功・田畑満生（編） 水産動物の日周活 動 第 6 章 恒星社厚生閣 Pp. 79-100.

Trevarthen, C. 1968 Vision in Fish: The Origins of the Visual Frame for Action in Vertebrates. In D. Ingle (Ed.), The Central Nervous System and Fish Behavior. Chicago: The University of Chicago Press.

辻 敬一郎 1978 心理学・行動研究と実験動物 田嶋嘉雄(編) 実験動物の開発 第 6 章 医歯 薬出版 Pp. 169-193.

Waxman, H. M. \& McCleave, J. D. 1978 Autoshaping in the archer fish (Toxotes chatareus). Behavioral Biology, 22, 541-544.

Woodard, W. \& Bitterman, M. E. 1974 Autoshaping in the goldfish. Behavior Research Methods \& Instrumentation, 6, 490-410. 